\title{
Bazı Sigorta Şirketi Yöneticilerinin Türkiye'de Özel Sağlık Sigortacılığı Üzerine Bir Değerlendirmesi
}

\author{
Haluk Özsarı'®e, Özden Güdük²®
}

${ }^{1}$ Acıbadem Mehmet Ali Aydınlar

Üniversitesi, Sağlık Bilimleri Fakültesi, İstanbul, Türkiye

${ }^{2}$ Türkiye Sağlık Enstitüleri Başkanlığı, Türkiye Halk Sağlığı ve Kronik Hastalıklar Enstitüsü, İstanbul, Türkiye

Haluk Özsarı, Prof. Dr.

Özden Güdük, Dr.
Illetişim:

Prof. Dr. Haluk Özsarı

Acıbadem Mehmet Ali Aydınlar Üniversitesi, Sağık Bilimleri Fakültesi, İstanbul, Türkiye Tel: +902165004190

E-Posta: haluk.ozsari@acibadem.edu.tr

\section{ÖZET}

Amaç: Bu çalışmada özel sağlık sigortacılı̆ııın mevcut durumu, sorunları, gelişimi için neler yapılması gerektiği ve geleceği hakkında profesyonellerin görüşleri derlenmiştir. Böylece sağlık politikaları ve finansmanı konusunda karar vericilere katkı sağlamak, aynı zamanda sağlık alanında çalıșan akademisyenlere ve öğrencilere ıșık tutmak amaçlanmıștır.

Çalışma Planı: Ülkemizde hizmet veren 39 özel sağlık sigorta şirketinin 8'inde üst düzey yönetici olarak görev yapan kişiler ile 2018 yilında Kasım-Aralık aylarında yüz yüze derinlemesine görüşmeler yapılmıştı. Literatür taraması ile oluşturulan, 12 adet yarı yapılandırıımıs soru sorularak ülkemizde özel sağlık sigortacılığııı hem destekleyici sağlık sigortası hem de tamamlayııı sağık sigortası yönüyle değerlendirmeleri istenmiștir. Çalıșmaya dâhil edilen sigorta șirketlerinin pazar payı toplamı \%82'dir. Görüșme yapılan sekiz kişinin özel sağlık sigortaclıı̆ı alanında çalışma süresi ortalaması ise 21,75 yıldır.

Bulgular: Gelişmiş ülkeler ile kıyaslandığında özel sağlık sigortacilığııın yeterince gelişmediği; sosyal sigorta kapsamının fazla geniş olması, sigorta bilincinin düşük olması ve kamunun sunduğu sağlık hizmetine duyulan güvenin buna neden olan en önemli etkenler arasında sıralanabileceği ifade edilmiştir. Bu kapsamda; hizmet sunumunda standardı olușturacak klinik rehberlerin bulunmaması, hastanelerin sunduğu hizmet maliyetlerindeki artışın primlere doğrudan yansıması, sigorta şirketleri ile hastaneler arasında yapılan bazı anlaşmaların sistemin işleyişini olumsuz etkileyerek dengeyi bozduğu belirtilerek; suiistimaller özel sağlık sigortacılığının önemli sorunları arasında gösterilmiştir. Hem finansal sürdürülebilirlik hem de vergi kaybını önlemek açısından devletin özel sağlık sigortacılığııı desteklemesi gerektiği ifade edilerek bu desteklerin; bireysel veya kurumsal vergi teşviki ya da zorunlu sosyal sigorta primlerinde azaltma şeklinde olabileceği önerilmiştir.

Sonuç: Özel sağlık sigortacılığııın ülkemizdeki durumu, sorunları, diğer ülke örnekleri ile farklııkları ve gelecek beklentileri ortaya konulmuştur. Özel sağlık sigortacılığııın, alternatif bir finansman kaynağı olarak ülkemiz sağlık sistemine uygun gelişimi için ileri çalışmalar yapılması önerilmektedir.

Anahtar sözcükler: Özel sağlık sigortası, sağlık finansmanı, tamamlayııı sağlık sigortası

\section{AN EVALUATION ON PRIVATE HEALTH INSURANCE IN TURKEY BY EXECUTIVES OF SOME INSURANCE COMPANIES}

\section{ABSTRACT}

Objectives: In this study, opinions of the professionals on the current status of private health insurance, needs for the development and the future of private health insurance are compiled. Thus, it is aimed to contribute to the decision-makers about health policies and financing, and also to shed light on academicians and students in the field of health.

Study Design: In this study; in-depth interviews were conducted with 8 of the 39 private health insurance companies serving in our country between November and December 2018.12 semi-structured questions, which were created by the literature review, were asked to evaluate private health insurance in terms of both health insurance and supplementary health insurance. The total market share of the included insurance companies in the study is $82 \%$. The average working time of the 8 people interviewed in the field of private health insurance is 21.75 years.

Results: Compared to developed countries, private health insurance is not sufficiently developed in Turkey; it is stated that social insurance coverage is very comprehensive, low awareness of insurance and trust in public health services can be listed among the most important factors. In this context; the absence of clinical guidelines to establish the standard of service provision; the direct reflection of the increase in the service costs offered by hospitals to the premiums; misconduct is one of the major problems of private health insurance. In order to prevent both financial sustainability and tax loss, the government should support private health insurance. It has been suggested that individual or institutional tax incentives or compulsory social insurance premiums reduction.

Conclusion: The current situation of private health insurance in our country, problems, differences with other countries and future expectations have been put forward. Further studies are recommended for the development of private health insurance as an alternative source of financing for our country's health system.

Keywords: Private health insurance, health finance, complementary health insurance
Gönderilme Tarihi : 25 Şubat 2019

Revizyon Tarihi : 02 Mayıs 2019

Kabul Tarihi $\quad$ : 05 Mayıs 2019 
D ünya Sağlık Örgütü (DSÖ)'ye göre iyi bir sağlık sisteminin amacl; bireysel beklentilere cevap verecek şekilde, tüm toplumun sağlıklı olma durumunu artırmak ve bireyleri sağlık harcamalarına karşı güvence altına almaktır (1). Bu amacına ulaşabilmek için sağlık sistemleri; yönetim, sağlık hizmetinin arzı ve finansmanı şeklinde ifade edilen fonksiyonlarını kullanır (2).

Sağlık hizmetleri için gerekli olan finansman, devlet eliyle sağlanabildiği gibi bazı durumlarda ve ülkelerde piyasa ekonomisinin hâkim olduğunu görülebilmektedir (3). Kaynak hangi yol ile sağlanırsa sağlansın, iyi yönetilen bir sağlık sisteminde arzu edilen şey; bireyleri beklenmedik durumda bile, karşı karşıya kalınan sağlık hizmeti maliyetinden korumaktır (4).

DSÖ, kendisine üye ülkelerden yaş, gelir, sağlık durumu ayrımı yapılmadan, toplumdaki her bireyin erişebileceği, evrensel kapsayıcılıkta bir sağlık sistemi oluşturmasını istemektedir. Fakat böyle bir sistemi kurmak için yanıtlanması gereken en önemli soru; finansmanın nasıl sağlanacağı ve sürdürüleceğidir (5). Artan yaşlı nüfus, kronik hastalıkların artması, hızlı gelişen teknoloji, kişilerin sağlık beklentisinin artması, arzın talep yaratması gibi pek çok husus yüzünden, dünyada önlenemez bir şekilde artan sağlık maliyetleri, hükümetleri sağlık finansmanı üzerine çözümler ve alternatifler araştırmaya yönlendirmiştir. Sağlık finansmanı giderlerini azaltmak veya gelirleri artırmak için ülkelerin uygulamaya koyduğu düzenlemelerden bazıları; sağlık hizmetleri için kullanıcılardan katkı payı alınması, hizmet sunucularına ödeme yaparken global bütçe yönteminin kullanılması, birinci basamak sağlık hizmet sunumunun güçlendirilmesi ve önceliklendirilmesi olarak sayılabilir. Bunlara ilaveten, farklı bir finansman kaynağı yaratmak için özel sağlık sigortasının teşvik edilmesine de rastlamaktadır $(2,6-8)$.

\section{Sağlık finansmanı yöntemleri}

Sağlık finansmanı sistematik bir yapıya kavuşmadan ve kurumsallaşmadan önce, dünya genelinde, toplumsal dayanışma ilkesi çerçevesinde gelişen, daha çok dini kuruluşlar vasıtasıyla ücretsiz sunulan sağlık hizmetleri görülmektedir. Ancak zamanla, sağlık hizmetinin doğası gereği ne zaman ihtiyaç duyulacağı veya ne kadar maliyeti olacağı gibi belirsizlikler içermesi nedeniyle, sağlık finansmanı için bir yapılanma gerekliliği ortaya çıkmıştır $(9,10)$.

$\mathrm{Bu}$ ihtiyaca istinaden, 19. yüzyılın sonlarına doğru Avrupa'da iş̧̧i ve işverenlerden toplanan primler ile finanse edilen ve günümüzde yaygın olarak kullanılan sosyal sağlık sigortasının ilk adımları atılmıştır. 20. yüzyılda ise öncülüğünü İngiltere'nin yaptığı, vergilerle finansmanı sağlanan ve ülke nüfusunun tümünü kapsayan yeni bir sistem ortaya çıkmıştır ve günümüzde Danimarka, Finlandiya, İrlanda, İspanya, İsveç, İtalya, Norveç, Portekiz, Yunanistan dâhil pek çok ülke tarafından kullanılmaktadır $(11,12)$. Kamusal sağlık sigortası olarak tanımlanan bu iki finansman yöntemi haricinde, bazı özel sağlık finansmanı çeşitleri de vardır.

Sağlık harcamaları finansmanında üçüncü bir tarafın olmadığı, hizmeti kullanan kişinin, hizmet sunan kişi ya da kuruluşa doğrudan yaptığı ödemeler cepten ödeme yöntemi olarak adlandırılır. Katastrofik etkiler doğurma ihtimalinden dolayı bu yöntemin kullanılması tercih edilmemektedir (13).

Bir diğer özel sağlık finansman yöntemi; ileride karşılaşılabilecek sağlık harcamaları için banka hesabında para bulundurmak yani tıbbi tasarruf hesabı açmaktır. Bu hesap sadece sağlık giderleri için kullanılır (3).

Bireylerin, sağlık konusunda taşıdıkları riskleri, belirlenen miktarda prim karşılığında, bir özel sigorta şirketine devretmesi ise özel sağlık sigortacılığıdır. Özel sağlık sigortasında primler çoğunlukla sigorta yaptırmak isteyen kişinin risk durumuna (yaş, sağlık durumu, cinsiyet vb.) ve talep ettiği teminatın kapsamına göre belirlenir. Teminatlar ayaktan veya yatarak teminatlar şeklinde iki ana gruba ayrılmaktadır. Bununla birlikte diş tedavileri, doğum, gözlük temini gibi ilave hizmetleri de kapsayan ek teminatlar ile kapsam genişletilebilmektedir $(14,15)$.

Ülkelerin sağlık sistemleri incelendiğinde ağırlıklı olarak yukarıdaki finansman yöntemlerinden birini tercih ettiği görülmektedir. Fakat riski dağıtmak ve farklı kaynaklara sahip olmak için aynı anda birden çok yöntemin bir arada kullanıldığına sıklıkla rastlanmaktadır (16).

Hem kamusal hem de özel sağlık sigortacılığında, temelde risk paylaşımı ilkesi vardır. Sisteme dâhil olan tüm üyeler, primler yoluyla katkı sağlamakta ve bu katkılar bir havuzda birikmektedir. Sağlık hizmetine ihtiyaç duyan üyelerin harcamaları bu havuzda biriken fondan sağlanmaktadır. Böyle bir sistemde sağlık durumu kötü olanlar daha sağlıklılar tarafından ve gelir durumu kötü olanlar daha yüksek gelirliler tarafından desteklenmektedir (17).

\section{Türkiye'de özel sağlık sigortacılığı}

Gelişmiş ülkeler ile kıyaslandığında Türkiye'de özel sağlık sigortacılığının çok geç başladığı ve yeterince gelişmediği 
görülmektedir (18). Bunda en büyük etkiyi ülkemizin Anayasa'nın 56. Maddesinde de belirtildiği üzere, sağlığı bir hak olarak tanıması ve sosyal sağlık anlayışını benimsemesi olduğu bilinmektedir $(19,20)$. Ancak zamanla sosyal güvenlik sistemi vasıtasıyla sunulan sağlık hizmetlerinin yeterince hızı olmaması, daha kaliteli hizmet arayışı gibi sebepler bireyleri özel sağlık kuruluşlarından hizmet almaya yönlendirmiş ve bu kuruluşlara yapılan cepten ödemelerin yerini özel sağlık sigortacılığı almıştır (17).

Türkiye'de sigorta branşları içinde sağlık sigortası nispeten yeni bir üründür ve toplam sigortacılık sektörü içinde $\% 13$ 'lük bir paya sahiptir ve yıllardır stabil durmaktadır (21). Ülkemizde özel sağlık sigorta ürünü sunan sigorta şirketlerinin sayısı yıllar içinde artış göstermiştir. Günümüzde toplam 39 şirket hizmet vermektedir, buna rağmen Tablo 1 'de de görüleceği üzere pazarın \%50'sinden fazlasına ilk iki şirket sahiptir.

OECD Raporu, özel sağlık sigorta çeşitlerini; birincil (principal-substitute; ikame edici-asıl), tamamlayıcı (complementary), tekrarlayıcı (duplicate) ve destekleyici (supplementary) olmak üzere dört gruba ayırır (22). Türkiye'de özel sağlık sigortası ilk uygulamaları destekleyici sağlık sigortası şeklinde ortaya çıkmıştır. Bununla birlikte Sosyal Güvenlik Kurumu'nun 2012/25 sayılı 'Tamamlayıcı veya Destekleyici Sağlık Sigortası Uygulamaları' başlıklı genelgesi ülkemizde tamamlayıcı sağlık sigortasının önünü açmıştır. Kamusal sağlık sigortasının kapsamı dışında kalan, kişinin cepten ödemesi beklenen hizmetlerin kapsam altına alındığı tamamlayıcı sağlık sigorta çeşidi, ülkemizde son birkaç yıldır sigorta şirketlerinin sundukları ürün yelpazesine katılmıştır ve hem bireysel hem de kurumsal müşteriler tarafından bu yönde talep artmaktadır (23).

Tablo 2'de görüldüğü üzere özel sağlık sigorta prim üretiminde her yıl artış olmaktadır. 2018 yılı sağlık sigorta prim üretimi \%24,2 artarak 6.244.361,48 TL'ye ulaşmıştır (21).

Sigortalı sayılarına bakıldığında; 2016'da destekleyici sağlık sigortası sahibi 2.273.215 kişi iken bu rakam 2017 yılı sonunda 2.026.458'e düşmüş ve 2018 yılında ise 2.223.758 olarak istatistiklere yansımıştır. Tamamlayıc sağlık sigortası ürününde ise aynı yıllar için sırasıyla; 404.975, 676.124 ve 920.073 kişi ile bir artış olduğu görülmektedir. Destekleyici ve tamamlayıcı sağlık sigortalı sayılarının son üçyıl karşılaştırması, ürünler arası bir miktar geçiş olduğuna işaret etmektedir. Ferdi ve grup sigortalar yönünden incelendiğinde 2017 yılında, destekleyici sağlık sigortasında; ferdi sağlık sigortalı sayısı 956.147 kişi ve grup sağlık sigortalı sayısı 1.070.311 kişi
Tablo 1. Sağlkk sigortası şirketlerinin pazar payı ve toplam prim değişimleri, Türkiye, 2018

\begin{tabular}{lccc}
\hline Sıralama & Şirket Adı & Toplam Üretim (TL) & Pazar Payı \% \\
\hline 1 & Allianz Sigorta AŞ & 2.200 .939 .419 & $35,25 \%$ \\
2 & Acıbadem Sağlık ve Hayat & 1.133 .616 .336 & $18,15 \%$ \\
& Sigorta AŞ & & \\
3 & Anadolu Anonim Türk & 710.921 .669 & $11,39 \%$ \\
4 & Sigorta Şirketi & & \\
5 & Mapfre Sigorta AŞ & 559.630 .189 & $8,96 \%$ \\
6 & Aksigorta AŞ & 276.733 .909 & $4,43 \%$ \\
7 & Axa Sigorta AŞ & 254.935 .946 & $4,08 \%$ \\
8 & Groupama Sigorta AŞ & 164.343 .643 & $2,63 \%$ \\
9 & Güneş Sigorta AŞ & 153.221 .918 & $2,45 \%$ \\
10 & Eureko Sigorta AŞ & 152.989 .718 & $2,45 \%$ \\
11 & Sompo Japan Sigorta AŞ & 95.116 .818 & $1,52 \%$ \\
12 & Ergo Sigorta AŞ & 84.340 .231 & $1,35 \%$ \\
13 & Demir Hayat Sigorta AŞ & 68.241 .083 & $1,09 \%$ \\
14 & Türk Nippon Sigorta AŞ & 66.303 .027 & $1,06 \%$ \\
15 & Doga Sigorta AŞ & 52.713 .941 & $0,84 \%$ \\
16 & Zurich Sigorta AŞ & 42.755 .755 & $0,68 \%$ \\
SEKTÖR TOPLAMI & Diğer & 227.557 .882 & $3,64 \%$ \\
\hline Türkiye Sigorta Birliği, https://www.tsb.org.tr/resmi-istatistikler.aspx?pagelD & \\
& & & $1000,00 \%$ \\
\hline
\end{tabular}

Tablo 2. Yillara göre özel sağllk sigortası prim üretimi, Türkiye, 2012-2018

\begin{tabular}{lcc} 
Yıl & Sağlık Branşı Prim Üretimi & Artış Oranı (\%) \\
\hline 2012 & 2.169 .818 .835 & 10,5 \\
2013 & 2.398 .077 .778 & 10,5 \\
2014 & 2.847 .809 .073 & 18,8 \\
2015 & 3.321 .928 .306 & 16,6 \\
2016 & 4.082 .408 .624 & 22,9 \\
2017 & 4.825 .757 .464 & 18,2 \\
\hline
\end{tabular}

Türkiye Sigorta Birliği, https://www.tsb.org.tr/resmi-istatistikler.aspx?pagelD=909

iken, 2018 yllında ferdi 1.002.483 ve grup 1.221.275 kişi olarak kayıt edilmiştir. Tamamlayıcı sağlık sigortasında ise ferdi sigortalı sayısı 2017 yılında 272.059 ve 2018 yılında 362.713 kişi, grup sigortalı sayısı da aynı yıllar için sırasıyla 404.065 ve 557.360 kişi olduğu görülmektedir $(24,21)$.

Hem bireysel hem de kurumsal sağlık sigortası poliçe sayılarında en büyük payın İstanbul ve ardından Ankara illerine ait olduğu görülmektedir. Üçüncü sırayı ise bireysel poliçelerde İzmir alırken, kurumsal sigortalarda Bursa almaktadır (25). 


\section{Gereç ve Yöntem}

Türkiye'de özel sağlık sigorta (ÖSS) ürünü sunan 39 sigorta şirketi bulunmaktadır (21). 2018 Kasım-Aralık aylarında yürütülen çalışmada bu şirketlerden 8'inde görev yapmakta olan toplam sekiz üst düzey yönetici ile yüz yüze derinlemesine görüşme yapılmış ve önceden hazırlanmış yarı yapılandırılmış soru formu üzerinden görüşleri alınmıştır. Her bir görüşme yaklaşık 60 dakika sürmüş ve daha sonra deşifre edilmek amacıyla görüşmelerin ses kaydı alınmıştır.

Çalışmaya dâhil edilen sigorta şirketlerinin Türkiye'de özel sağlık sigortacılığında toplam pazar payı \%82'dır. Görüşme yapılan yöneticilerin biri genel müdür, ikisi genel müdür yardımcısı, beşi ise sağlık sigorta departmanı müdürü/koordinatörü olarak görev yapmaktadır. Sağlık sigortacılığı alanında görev yapma yılları en az 14 yıl ve en fazla 30 yıl arasında değişmekte ve ortalaması 21,75 yıldır. Bu çalışmada görüşme yapılan kişi ve şirket isimlerini kullanmak yerine A şirketi yöneticisi, B şirketi yöneticisi şeklinde kodlama yapılmıştır.

\section{Bulgular}

Literatür taranarak hazırlanan, yarı yapılandırılmış sorular üzerinden gerçekleştirilen her bir görüşmede, katılımcıların konu hakkında görüşleri alınmıştır. Toplam 12 soru yöneltilen her görüşmede, katılımcıların bilgisi ve izni dâhiline ses kaydı alınarak sonradan deşifre edilmiştir.

\section{Özel sağlık sigortacılığının ülkemizdeki mevcut durumu} Yapılan görüşmelerden elde edilen bilgiler şunları göstermektedir: Gelişmiş ülkeler ile kıyaslandığında Türkiye'de özel sağlık sigortasının yeterince gelişmediği görülmektedir. Ülke nüfusunun sadece \%2,5-3'lük bir kesimi özel sağlık sigortası sahibidir (Tamamlayıcı Sağlık Sigortası -TSS- dâhil) ve bu oran görüşme yapılan sağlık sigortası yöneticilerine göre oldukça düşük kabul edilmektedir. Buna rağmen, yapılan pazar araştırmalarına göre, özel sağlık sigortası yaptırma gücü olan bireylerin, nüfusun \%10'una denk geldiğini bilinmektedir. Yani hala önemli potansiyel bulunmaktadır. Ama bir takım sebeplerden dolayı ülkemizde özel sağlık sigortası yaptırma yönünde isteklilik azdır. Bunlar;

- Ülkemizde sosyal sağlık politikasının benimsenmesi

- Bireylerin sigorta bilinçliliğinin düşük olması

- Sosyal sağlık sigorta kapsamının çok geniş olması

- Bireylerin ekonomik alım gücünün düşük olması

- Kamunun sunduğu sağlık hizmetine duyulan memnuniyet olarak ifade edilmiştir.
Bu çalışma kapsamında yapılan görüşmelerde, özel sağlık sigortaclığının, devletin temel sağlık politikasından ayrı düşünülemeyeceği ve Türkiye'nin sosyal bir devlet anlayışı benimsemesi nedeniyle gelişiminin yavaş olduğu sıklıkla ifade edilmiş̧ir. Tüm görüşmecilerin düşüncelerini özetleyen B şirketi yöneticisi "Ülkemizde sosyal sigortacılık çok geniş bir kapsam sunuyor, pek çokülkede olmayan güvenceler var. Vatandaş açısından bakıldığında oldukça iyi bir koruma ama finansman yönüyle düşünülünce sürdürülebilirliği zor." demiştir.

Özel sağlık sigortalı sayısında yeterince artış olmamasını D şirketi yöneticisi "Ülkemizde özel sağılk sigortacılığı, Sosyal Güvenlik Kurumu'ndan hizmet talep etmeyen, A-B gelir grubuna dahil küçük bir kesim ile sınırlı kaldı, o yüzden bu kadar az sigortalı var" sözleri ile açıklamıştır. Yine $C$ şirketi yöneticisi "Kişiler başına bir olay gelmediği sürece sigorta satın alma ihtiyacı hissetmiyor. Sigortaya verilen paranın boşa giden bir para olduğunu düşünüyor" ifadesini kullanmıştır.

Son yıllarda sağlık alanında yapılan düzenlemeler, yenilenen hastane binaları ve hizmete erişimin kolaylaştırılması gibi nedenler bireylerin kamu hastanesinden almış oldukları hizmetten memnuniyeti artırmıştır. E şirketi yöneticisi bu durumu şu sözleri ile ifade etmiştir; "Toplumun büyük bir kesimi, devletin sunduğu hizmetten memnun. Üst seviyede gelire sahip küçük bir grup memnuniyetsiz". Özellikle Anadolu şehirlerinde, kamu sağlık hizmetine duyulan memnuniyet ve erişimde bir sıkıntı yaşanmaması, bireylerin özel sağlık hizmetine ihtiyaç duymamasına neden olmaktadır. D şirketi yöneticisi "Küçük şehirlerde hastanelere ya da aile hekimliğine erişimde bir sıkıntı yaşanmıyor ama metropollerde kalabalık nüfusun yarattı̆ı sağlığa erişim sorunu mevcut. Özel sektör nüfusun ve talebin yüksek olduğu bu şehirlere yatırım yaparak kamunun sunduğu sağlık hizmet sunumuna alternatif oluşturuyor" şeklinde açıklamıştır.

Benzer şekilde C şirketi yöneticisi "ÖSS talep sebepleri otelcilik ve konfor üzerine olduğu için bu eksiğin olmadığı, kamu hastanelerinin yeni ve bakımlı olduğu az nüfuslu şehirlerde bu yönde talep olmuyor" ifadesini kullanmıştır.

Türkiye'de özel sağlık sigortasının algılanışı ve kullanımı ile diğer ülkelerde kullanımı arasında farklılık olduğuna değinen B şirketi yöneticisi, bunu şu sözleri ile ifade etmiştir "Türkiye'de özel sağlık sigortacılığının aksettirilmesi farklı oldu. Özel sağık sigortacılığın mantığında bu yok iken, ülkemizde lüks ile eşdeşleşmiş durumda". E şirketi yöneticisi "Ülkelerin kendi sosyoekonomik durumlarına göre farklı anlayışlar var. Avrupa'da özel sağlık anlayışı ile Türkiye'de anlayış daha farklı" demiştir. 
A şirketi yöneticisi ise "farklı ülkeler ile ülkemizin kıyaslamasını yapmak biraz zor çünkü sağlık sistemleri birbiri ile aynı değil. Hiçbir ülkede bizim kadar geniş bir sosyal sağlık sigortası yok. Almanya'da özellikle tamamlayıcı sigortada bir gelişim sağlandı. Bunun sebebine baktığımızda Almanya'da sosyal sağlık sigorta kapsamının dar olduğunu; diş, özellikli işlemler gibi hizmetler için kişilerin tamamlayıcı sigortaya yöneldiğini görüyoruz." sözlerini aktarmıştır.

Türkiye'deki sistemin farklılığından kaynaklanan bir soruna değinen G şirketi yöneticisi "yurtdışında hastaneler tüm sigorta şirketleri için aynı oranda bir fiyat belirliyor, her sigorta şirketine aynı fiyat üzerinden fatura kesiyor. Bizde ise şirketler ile hastaneler arasında sürekli bir pazarlık yaşanıyor. Büyük bir pazar payına sahip şirketler hastanelerden daha iyi indirimler alabiliyor, bu da sağlık sigortacılığının tekelleşmeye doğru gitmesine sebep oluyor" şeklinde açıklama yapmıştır.

\section{Özel sağlık sigortacılığının ülkemizdeki sorunları}

Özel sağlık sigortacılığının gelişmesinin önündeki engeller sorulduğunda; görüşme yapılan yöneticilerin hepsi, Türkiye'deki sorunlardan birini sağlık hizmet sunucusunun karar vermede çok serbest olması olarak tanımlamıştır. Klinik rehberlerin yetersiz olduğuna ve var olanların ise uygulanmadığına değinerek, sağlık hizmetlerinin asimetrik bilgi özelliğinin bazen arz tarafından kaynaklı hizmetlerin aşırı ya da gereksiz kullanabilmesine yol açtığını ifade etmişlerdir. Sağlık hizmetlerinin ticarileşmeye çok müsait bir yapısı olduğuna değinerek böyle bir durumun sigorta primlerinde artışa neden olarak sistemi olumsuz etkilediğini açıklamışlardır. Benzer şekilde hastane faturalarının, finansman yöntemine göre değişkenlik gösterdiğini, özel sağlık sigortası olanlar ile genel sağlık sigortası olanlar ve cepten ödeme yapanlar arasında alınan hizmetin ve ödenen miktarların farklı olduğunu ifade etmişlerdir.

Kontrol mekanizmalarına duyulan ihtiyacı C şirketi yöneticisi şu şekilde açıklamıştır: "Sağlığın gereğinden fazla tüketilmesi sorunu yaşanıyor. Sağlık tüketimini ve sağlık hizmet sunumunu kontrol edecek mekanizmaların olmaması bir eksiklik. Hizmet sunan tarafın da özel sağlık sigortacılığın gelişmesi için sorumlulukları olduğunun bilincine varması gerekir."

B şirketi yöneticisi sağlık sigortacılığının suiistimal edinmesine değinerek kanıtlamanın zorluğundan ve kanıtlandığı durumlarda da yaptırımların eksikliğinden bahsetmiştir. "Hastane çalışanları veya doktorlar bazen hastaya iyilik yaptığını düşünerek bazı durumları sigortanın ödeyeceği şekilde rapor ediyor. Örneğin uzun süredir olan bir hastalığı sanki yakın zamanda olmuş gibi gösterebiliyorlar. Oysaki bu davranış o hastaya faydalı olsa bile geniş açıdan düşünüldügü̈nde maliyet artışına ve dolayısı ile diğer sigortalıların da primlerinde artışa neden oluyor. Bu tür davranışlarda bulunmanın bir cezai yaptıımı da yok. Suiistimali ile karşılaşıldığında ve fark edildiğinde yapılan tek şey o işlemi ödememek, sigortalı yerine başka birisinin sağlık hizmeti alması gibi bariz durumların dışında suiistimali kanıtlamak çok."

Bazı durumlarda ise talep taraflı aşırı hizmet kullanımı olduğuna dikkat çeken E şirketi yöneticisi "Sigortalılarda bu kadar para ödedim hiç kullanmadım, bari bir iki kere hastaneye gideyim gibi bir düşünce var" diyerek bu durumu açıklamıştır.

Hizmet kullanımı açısından bireysel ve grup sigortalıların farklı davranışta bulunduğunu ifade eden $\mathrm{G}$ şirketi yöneticisi "Bireysel sigortalı olanlar daha bilinçli tüketici olurken, grup sigortalar özellikle yeni sigortalanmış gruplarda kullanım daha aşırı olabiliyor. Ama uzun süredir sigortalı olan gruplarda davranışlar bireysele benzerlik gösteriyor" demiştir. Bu davranışın sigorta şirketlerinin istatistiklerine de yansıdığını ve açıkça görülebildiğini şu sözleri ile açıklamıştır "Genelde senenin son ayları grup poliçelerinin yenilenme zamanıdır, bu yüzden hizmet kullanımı da bu aylarda artış gösterir".

Özel hastanelerin otelcilik hizmetlerinin, sağlık hizmeti maliyetini ve dolaylı olarak sağlık sigortası primlerini artırdığını söyleyen B şirketi yöneticisi "Birçok ülkede bu kadar yüksek standartta otel bile bulamazsınız. Körfez ülkeleri, Singapur, Hindistan gibi ülkelerde buna benzer otelcilik hizmetlerinin abartıldığı hastaneler var. Ama Avrupa'da özel hastaneler ile kamu hastaneleri arasında bariz bir fark yok, öğleden önce kamu hastanesi olarak çalışan hastaneler öğleden sonra özel hizmet veriyor" şeklinde açıklamada bulunmuştur.

Özel sağlık sigortası alanında ülkemizde yaşanan sorunlardan birini özel hastaneler ile olan ilişkiye dayandıran D şirketi yöneticisi "Ülkemizde iki sağlık sigorta şirketi, pazarın \%50'sinden fazla paya sahip. Yüksek paya sahip olmasından dolayı hastanelerden ciddi indirim alabiliyorlar, hastaneler ise bu şirketlerin pazardan çıkması endişesi ile indirim yapmayı kabul ediyor. Bu durum bir mutsuzluk yaratıyor." açıklamasını yapmıştır.

"Sigorta şirketleri arasında bir kopma başladı. Şirketler sürdürülebilirlikten endişe duyduğu için pazardan çıkmaya başııyor" diyen E şirketi yöneticisi de aynı soruna değinmiştir. 
Görüşmelerde ifade edilen, özel sağlık sigortacılığının ülkemizde gelişmesi önündeki sorunlar aşağıdaki şekilde özetlenebilir;

- Sağlık hizmet sunumunda standardizasyonun olmaması, klinik rehberlerin eksikliği

- Hastane faturalarının finansman yöntemine göre değişkenlik göstermesi

- Kontrol mekanizmalarına duyulan ihtiyaç

- Arz ve talep taraflı suiistimaller

- Gereksiz ve aşırı hizmet kullanımı

- Otelcilik hizmetlerinin sağlık hizmeti maliyetini ve dolaylı olarak sağlık sigortası primlerini artırması

- Sigorta şirketleri arasında pazar payındaki dengesizlik

\section{Özel sağlık sigortası ile ilgili mevzuat}

Görüşme yapılan tüm yöneticiler, mevcut mevzuatın şu anki durum için yeterli olduğunu; satış, satış sonrası, bilgilendirme zorunluluğu, yenileme garantisi gibi pek çok konuya kapsamlı bir şekilde açıklık kazandırdığını; sigortacılık sektörünü kontrol eden ve disiplinli bir şekilde yürümesini sağlayan yapıda olduğunu belirtmiştir. Fakat uzun dönemli sigortacılığın gelişebilmesi için mevzuat çalışması yapılabileceği ifade edilmiştir. E şirketi yöneticisi bu durumu şu sözleri ile açıklamıştır; "Sigorta satın alma kararında bireylerin sürdürülebilirlik konusunda kaygısı var, bunlara cevap verebilecek bir yapı kurmak lazım". Bir başka görüşmeci ise farklı bir konuya değinerek "Bireyin eski sigortalı olmadan kaynaklı kazanımları gibi şirketler arasında geçişlerde hala düzenleme gerektiren konular var" demiştir.

Ayrıca G şirketi yöneticisi "Diğer mevzuatın düzenlenmesinde sigorta şirketleri hiç hesaba katılmıyor ve bazı durumlarda yeni çıkan farklı mevzuatlar sigorta şirketlerini negatif etkiliyor. Ticaret Kanunu veya Kişisel Verinin Korunması Kanunu (KVKK) gibi düzenlemeler yapılırken, ödeyici bir kurum olarak bizlerde göz önünde bulundurulmalıyı" demiştir.

"Sağlık alanında küçülen sigorta şirketleri var, açıkça görülüyor. Başka bir branşta örneğin kasko ürününü bırakmak şirketler için daha kolay ama sağlık için bu durum geçerli değil. Ömür boyu yenileme garantisi olanlar, poliçe yapıldıktan sonra hastalananlar var. Şirketin kapanması halinde bu sigortalıların durumunu düzenleyen bir mevzuat yok" diyerek E şirketi yöneticisi bu yönde bir düzenlemeye duyulan intiyacı dile getirmiştir.

\section{Özel sağlık sigortası için devlet teşviki}

Yaşlanan nüfus, kronik hastalıklar, sağlık hizmetine talebin artması, teknoloji gibi unsurların sağlık hizmetleri maliyetini artırdığı, tüm dünyada olduğu gibi ülkemizde de sağlık hizmeti finansmanının gittikçe sorun haline gelmeye başladığı, devletlerin finansman yükünü paylaşabileceği bir mekanizmaya intiyaç duyduğu belirtilmiş ve ilave finansman kaynağı için en uygun seçeneğin ÖSS olduğu ifade edilmiştir.

Ülkemizde de, Sosyal Güvenlik Kurumu (SGK)'nun topladığı gelirlerin giderleri karşılamakta yeterli olmadığı ve sistemin, devlet tarafından vergiler ile desteklendiği göz önünde bulundurulursa, sağlık finansmanı yönünden sıkıntı yaşandığı görülebilmektedir.

Bununla birlikte, özel sağlık sigortasının kayıt dışılığı önlemesi nedeniyle de dolaylı pozitif etkisi unutulmamalıdır. Görüşme yapılan yöneticiler tarafından, sağlık hizmet sunucularına yapılan cepten ödemelerin kayıt dışı olabileceği ve bunun vergi kaybına yol açabileceği ama sağlık sigortası ile bu durumun önlenebileceği ifade edilmiştir.

\section{Teşvik mekanizmaları}

Teşvik mekanizmalarının devreye sokulmasının hükümetin sağlık politikaları ile sıkı bir ilişki içinde olduğuna değinilmiş ve doğru bir yapılanma kurulur ise bazı teşvik mekanizmalarının faydalı olacağı söylenmiştir. Görüşme yapılan kişiler teşvikler için farklı senaryolar ve birden çok öneri bildirmiştir. Bunlar aşağıdaki maddeler halinde sunulmaktadır.

- Sigortalıların üzerindeki maliyet yükünü (iki kere prim ödemek) azaltmak açısından bir yapılanma kurulabileceği, ÖSS yaptıranlardan SGK prim oranlarının düşürülebileceği,

- Özel sağlık sigortası yaptıranlara yönelik mevcut vergi indirimlerinin yetersiz olduğu, üst limit uygulaması yüzünden etkili olmadığı, yeniden düzenlenerek üst limitsiz, bireye özgü vergi indirimleri ile daha işlevsel hale getirilmesi gerektiği,

- Çalışanlarına sağlık sigortası yaptıran firmalara yönelik vergi indirimleri sağlanabileceği,

- Bireysel emeklilik sistemi için yapılan teşvik ve kampanyaların benzerinin özel sağlık sigortası için de uygulanabileceği ifade edilmiştir.

ÖSS sahiplerinin GSS kapsamından çıkabilmesine imkân tanınmalı mı sorusuna yanıt veren A şirketi yöneticisi "Sosyal sağlık sigortası bir sosyal dayanışma mantığı üzerine kuruludur. Geliri yüksek olan düşük olanı, sağıklı olan hasta olanı destekler. Ben geliri yüksek olanların sistemden çıkmasını doğru bulmuyorum. Geliri yüksek ama sosyal sigortasını kullanmayanlar da sistemde kalarak sistemin dayanışma haline katkıda bulunmalıdır" demiştir. B şirketi yöneticisi 
ise şu ifadeleri kullanmıştır "Yüksek gelire sahip birisinin SGK'ya ödediği primler aslında en pahalı özel sağlık sigorta poliçesinden bile fazla. Ama sosyal güvenlik sistemini finanse eden kişiler de bunlar. Sosyal dayanışma mantığına göre düşünürsek ülkemizde gelir durumu yüksek kişilerin sistemden ayrılmasına izin verilmez."

Uzun dönemli sigortacılık için vergi indirimlerinin gerekli olduğunu vurgulayan A şirketi yöneticisi "Özellikle daha genç yaşta sisteme girenlerin prim ödemeleri ile daha ileri yaşlarda sisteme girenlerin yaptığı prim ödemeleri arasında hakkaniyet sağlayabilmek amacıyla bir vergi indirimi uygulanmalıdır" demiştir.

\section{Türkiye'de tamamlayıcı sağlık sigortası}

Alt ve orta gelirli kesime hitap edebilmek ve sisteme taze kan getirebilmek amacıyla TSS'nin 5510 sayılı Kanunu'nun 98'inci maddesine eklenmesi ve ardından SGK'nın 2012/25 sayılı Genelgesi ile uygulama düzenlenmiş olmasına rağmen, sigorta şirketleri tarafından bu ürünün piyasaya sunulmasının zaman aldığı ve ancak son birkaç yıl içinde gelişmeye başladığı söylenmiştir. Görüşme yapılan yöneticiler tarafından sigorta şirketlerinin TSS ürünlerini sunmasının ardından bir miktar destekleyici özel sağlık sigortalısının özellikle grup sigortalıların TSS ürünlerine geçiş yaptığının gözlendiği de bildirilmiştir.

Görüşme yapılan yöneticilerden elde edilen bilgiler derlendiğinde şu sonuçlara ulaşıımıştır; sektörün, TSS ile daha ciddi bir büyüme beklediğini ancak istenilen oranların yakalanamadığı ifade edilmiştir. Bunun en büyük nedeni olarak ise SGK kapsamının çok geniş olması ve tamamlanacak bir alan bırakmaması olarak gösterilmiştir. Bir diğer önemli sebep ise özel hastanelerin Sağlık Uygulama Tebliği (SUT) fiyatlarının \%200'ünden çok daha fazla talep etmesi şeklinde açıklanmıştır. Yapılan görüşmelerde sigorta şirketi yöneticileri tarafından "Kanuni düzenlemeler, özel sağlık sunucularının faturalama yaparken, cepten ödeme yapan kişilerden SUT fiyatının en fazla \%200'üne kadar fark talep edebilmesine imkân verirken, sağılk sigortaları tarafından ödeme yapıması durumları için bir üst sınır tanımamaktadır. Özel sağlık sunucularının, sigorta şirketlerinden bu oranın çok üstünde fark talep etmesi doğal olarak TSS primlerine yansımakta ve haliyle bireyler kendileri fark ödeyerek hizmet alacağı miktarlardan daha yüksek oranda prim ödemekle karşı karşıya kalmaktadır. Bu durum bireylerin TSS talebini azaltmaktadır" ifadeleri kullanılmıştır.

Anadolu'da pek çok özel hastanenin, kapı müşterisi diye de adlandırılan ve cepten ödeme yapan kişilerden fark ücreti almaması ya da çok düşük miktarda fark ücreti alması nedeniyle bu bölgelerde yaşayanların TSS'ye gerek duymadığı görüşmeciler tarafından sıklıkla ifade edilmiştir.

Sosyal Güvenlik Kurumu'nun SUT fiyatlarında artış yapmaması nedeniyle zaman geçtikçe sigorta şirketinin ödediği miktarın sürekli yükseldiği de bir başka olumsuzluk olarak gösterilmiştir. "SGK'nın kendi yapısına getirdiği her değişiklik bu sistemi etkiliyor. SGK'nın ödeme kapsamına aldığı her yeni hizmet bilgilendirme yapılmamış olsa bile, otomatik olarak şirketler tarafından kabul edilmiş oluyor" diyen E şirketi yöneticisi sistemin bir başka açığına değinmiştir.

TSS için düzenleme yapılması gerekliliği vurgulanarak fiyat protokolleri ve fark protokollerinin belirlenmesi gerekliliği ifade edilmiştir. Eğer doğru bir düzenlemeye gidilmezse TSS ile destekleyici sağlık sigortası arasında bir fark kalmayacağı söylenmiştir.

F şirketi yöneticisi TSS ürününde yaşanan değimi "Başlangıçta yalın TSS ürünleri çıkarıldı örneğin senede 5 muayene hakkı gibi (bizim portföyümüzde rakamlar bu orada idi, ona göre sayı belirlendi). Frekansın ÖSS'ye paralel olacağını düşünmüştük ama SGK'ya paralel gitti. Sigortalılardan yüksek talepler geldi, hem SGK anlaşması olsun hem A grubu hastanelerde geçsin gibi. Ürünlerde değişimler oldu. Zaman içinde hibrid (karma) ürünler gelişti; SGK anlaşması olmayan bir hastaneye gidildiğinde ÖSS özelliği olan, SGK anlaşması olan hastanelerde ise TSS gibi çalışan ürünler ortaya çıktı" sözleri ile özetlemiştir.

\section{Sağlık sigortacılığının gelişimi için neler yapılabilir}

$\mathrm{H}$ şirketi yönetici ÖSS sistemini çıkmaza sokan durumu risk dağılımında dengesizlik olarak tanımlamış ve bunun sebebini şu şekilde özetlemiştir: "Özel sağlık sigortacılığında, tazminatın farklı maliyetlerdeki hastanelerde homojen dağılımını sağlamak, hem satın alınabilir primlerle poliçe yapma hem de günün sonunda şirketlerin zarar etmeden hizmeti devam ettirebilmesi için çok önemlidir. SGK anlaşmalı hastanelerin hizmet kalitesine baktığınızda SGK ile hizmet alan hastaya verilen hizmet ile özel sağlık sigortalıya verilen hizmet arasında bir kalite farkı yok. Ama hastaneler SGK'Iı ve ÖSS'li hastaların hizmet fiyatlamasını aynı yapmak istemiyor. Günün sonunda aynı hizmeti farklı primle satmaya çalıştığınız için özellikle kurumsal müşteriler TSS'ye doğru kayıyor. Fazla ödeme yaparak özel sigorta alan sigortalılar da SGK anlaşması olmayan ve maliyeti yüksek olan kurumlara gitmeyi tercih ediyor. Bu da tazminatın homojen dağılımına engel oluyor. Hem mevcut sigortalı portföyün TSS'ye kaymasını engellemek hem de prim seviyesinin aşağı çekilerek 
sigortalı penetrasyonunun artmasını sağlamak için hizmet sunucuların özel sigorta sahipleri için sundukları değer önermelerini ortaya koyması gerekir".

Görüşme yapılan iki yönetici tarafından, SGK'nın bazı ileri sağlık hizmetlerini ödeme kapsamından çıkarması, bunları risk paylaşımı yaparak özel finansmana yüklemesi, böylece hem devletin üzerinde yükün hafifleyeceği hem de bireylerin finansmana katkıda bulunmasının sağlanacağı söylenmiştir. Bu tür bir düzenleme ile kamu hastanelerinin de özel sağlık sigortacılı̆̆ gibi ek bir kaynağa erişebileceği, üniversite hastaneleri başta olmak üzere birçok araştırma hastanesinin (SUT yetersiz olduğu için) gelirinin artıracağı açıklanmıştır.

Gelişmiş ülkelerde olduğu gibi ülkemizde de klinik rehberlerin kullanımının zorunlu olması, hastalara istenilen tetkik ya da işlem sayısında azalmaya, haliyle hastane faturasının ve sigorta prim ücretlerinin düşmesine yol açarak bireylerin özel sağlık sigortası yaptırma yönünde düşüncelerini olumlu etkileyeceği de çalışma kapsamında yapılan görüşmelerde sıklıkla ifade edilen konulardan biridir. Aynı şekilde aşırı büyüklükte hasta odalarının, hasta tedavisinin dışında kullanılan alanların, sosyal alanların hastanelerin işletme giderlerini yükselttiği ve bu işletme maliyetin hasta faturalarına yansımasının da negatif etkisine değinilmiştir.

Görüntüleme merkezi, hastane gibi özel sağlık sunucularının kontrolsüz artışının aşırı hizmet kullanımını doğurması nedeniyle hükümetin bu konuda kontrolü sağlamasının gerekliliği de ifade edilen bir başka konudur. Bir benzer eleştiri ise yeni tıbbi teknolojiyi kullanma oranlarının çok yüksek olması üzerine yapılmıştır, örneğin; laparoskopik yöntemle yapılabilecek müdahalelerin bile robotik cerrahi ile yapılıyor olmasının maliyetleri artırdığı ifade edilmiştir.

Sonuç olarak tüm yöneticilerin ortak ifadesi; sağlık sigortacılığının tek başına sigortacıların ya da tek başına hizmet sunucuların alanına bırakılmaması ve tüm paydaşların katılımı ile bazı düzenlemelerin yapılması gerektiği şeklinde olmuştur.

\section{Ekonomik durumun özel sağlık sigortacılığına etkileri}

Ekonomik sıkıntıların yaşandığı dönemlerde ilk etkilenen sektörlerden birinin sigorta sektörü olduğu ve özel sağlık sigortacılığının mevcut durumdan etkileneceği açıklanmıştır. Sigorta çeşitlerine göre farklı tepkiler görüleceği örneğin; ömür boyu yenileme garantisi olan destekleyici sağlık sigortası sahiplerinin hak kaybı yaşamamak için sistemden tamamen çıkmak yerine teminat paketini daraltmayı tercih edebileceği, kurumsal sigortalarda TSS ürünlerine geçişler olabileceği ifade edilmiştir. $G$ şirketi yöneticisi bireysel sigortalılar için öngörüsünü "Bireysel sigortalar içinde ÖSS'ye çok alışan bir kesim var. Yıllardır sigorta yaptıran, kaliteye alışan bir grup kolay çıkmayacaktır" sözleri ile açıklamıştır.

Sağlık sigortacılığında ekonomik durumun yansımasının henüz görülmediği, mevcut poliçelerin süresinin dolduğu zaman yenileme yaptırma oranlarının daha net bir analiz yapılmasını imkan vereceği belirtilmiştir.

Türk Tabipler Birliği (TTB)'nin yılbaşında açıklayacağı tıbbi enflasyon rakamının ve hizmet ücretleri tarifesinin beklendiği, tüm görüşmecilerin üzerine vurgu yaptığı bir nokta olmuştur. Hastanelerin fatura bedellerini belirlemesinde bu enflasyon rakamının etkili olduğu ve bu yıl geçen yıllara kıyasla çok daha yüksek çıkması beklenildiği açıklanmıştır. Yüksek hizmet bedellerinin sigorta primlerini doğrudan artıracağı ve daha yüksek olan primlerle sigorta ürünlerinin satışının daha zor olacağı, ekonomik durumun belirsiz olduğu bu dönemde kişileri sigorta ürünü almaktan vazgeçme yönünde etkileyeceği söylenmiştir.

Genel kanaat sigortalı sayısı azalmasa bile daha ekonomik paketlere geçiş nedeniyle prim üretiminin azalacağı yönündedir.

F şirketi yöneticisi sigorta şirketlerinin yüzleşmek zorunda olduğu bir başka konuya dikkat çekerek; "Enflasyon artışı olmadan önce satılan poliçeler bu artışöngörülemeden hesaplanmıştı ama bir yıl boyunca alacakları hizmet fiyatları birden artış oldu, bu durum sigorta şirketlerinin önümüzdeki yıl mali tablolarında görülecektir" demiştir.

\section{Türkiye'de özel sağılk sigortacılığının geleceği}

Sistemi genişletmeye yönelik düzenlemeler yapılmaz ise mevcut durumun devam edeceği ancak uygun düzenlemeler ile özel sağlık sigortalı sayısının, ülke nüfusunun \%10'unu kadar çıkabileceği belirtilmiştir. TSS talebinde bir miktar daha artış olacağı da öngörüler arasında olmuştur.

Özel sağlık sigortacılığının geleceği konusunda uzun dönemli sigorta konusunda farklı fikirler olduğu görülmüştür. Görüşme yapılan yöneticilerin 3'ü ülkemizde uzun dönemli sigortacılığa doğru gidilmesi gerektiği yönünde görüş bildirirken, bunlardan ikisi yaşlı bakımı konusunda bazı çalışmaların olduğundan bahsetmiştir.

Ancak diğer görüşmeciler uzun dönemli sigortacılığı konuşmak için erken olduğunu ifade etmişlerdir. F şirketi yöneticisi "Uzun dönemli sağlık sigortacılığı için çok uzun 
bir dönemin öngörülebilir olması lazım ama bu ekonomik koşullar ile öngörmek çok zor. Kişinin 30 yaşında sisteme girdiğini farz edersek 75-80 yaşına kadar geçecek 45-50 yılı iyi hesaplamak gerekir. Sigortacılıkta ileriyi öngörmek çok önemli, tahminlemelerin çok yüksek kalitede olması gerekir" diye açıklama yapmıştır. D şirketi yöneticisi yüksek enflasyon nedeniyle sigorta şirketlerinin uzun dönemli sağlık sigortasına sıcak bakmadığını söylemiştir.

B şirketi yöneticisi "Ülkemizin uzun dönemli sigortaya hazır olduğunu düşünmüyorum. Almanya dışında uzun dönemli sigortayı tam anlamıla yürüten ülke yok. Sağlık hizmeti maliyetlerinin artış göstermesi, tıp alanında gelişmelerin çok hızlı yaşanması nedeniyle sigorta şirketleri uzun dönemli poliçe satmak istemiyorlar"

C şirketi yöneticisi "Uzun dönemli sigortacılığın ülkemizde kullanımı için yeterli bir ortam olduğunu düşünmüyorum. Ama böyle bir uygulamaya geçilmesi düşünülürse sigorta şirketleri çok çabuk adapte olabilecek kapasiteye sahipler. Sigorta şirketlerinin yurtdışı ortaklıklarının olması bu adaptasyon sürecini hızlandıracaktır" demiştir.

Gelecekte mobil uygulamaların ve internet kullanımının sisteme dâhil olacağını söyleyen $\mathrm{H}$ şirketi yöneticisi "dijitalizasyon ile sağlık sigortasının yönetimi kişinin kendi elinde olabilecek. Mobil aplikasyonlar ve web kullanımı aynen bankacılıkta olduğu gibi yaygınlaşacak, sigortalılarımız ve sigortacıları online konuşacak ve işlemler çok daha kolaylaşacaktır" sözleri ile konuyu farklı bir yönden değerlendirmiştir.

\section{Dünyada özel sağlık sigortacılığının geleceği}

Görüşme yapılan yöneticiler tarafından, dünyada sağlık harcamalarının artışına bağlı finansman sorunu yaşandığı ve hükümetlerin gittikçe ağırlaşan finansman yükünü paylaşmak için alternatif yöntemlere yöneldikleri ifade edilmiştir. Bu aşamada sağlık riskinin paylaşımında bireylerin daha fazla sorumluluk alması teşvik edildiğine ve birçok ülkede TSS modellerinin yaygın kullanımına dikkat çekilmiştir.

Bazı ülkelerin sürdürülebilir yapılar kurduğuna değinen $\mathrm{E}$ şirketi Yöneticisi, İsrail örneğini vererek "Israil'de sigortalılardan iki çeşit poliçe alınır. Birincisi o dönem ortaya çıkacak riskler için kullanmak amaçlı, diğeri ise ileride ortaya çıkacak riskler için fon oluşturmak amaçlı. Sigortalı bir şirketten başka bir şirkete geçerken fonları ile birlikte geçiyor. Bu yapı, birey açısından sürdürülebilirliği sağlıyor" demiştir.
Kişisel Verilerin Korunması Kanunu (KVKK) özel sağlık sigortacılığına etkileri

H şirketi yöneticisi "KVKK birçok noktada özel sağlık sigortası sektörünü etkiliyor. Sağlık verileri özel nitelikli kişisel veri konumundadır. Bu verilerin saklanması, işlenmesi ile ilgili özel prosedürler oluşturulması, çalışanların bu konuda bilgilendirilmesi sorumluluğunu mevzuat sigorta şirketlerine yüklüyor. Dolayısı ile yapılan her iş geliştirmesinde KVKK'ya uygunluğun mutlaka gözetilmesi gerekiyor" demiştir.

Çalışma kapsamında görüşme yapılan bütün yöneticiler sigorta şirketlerinin KVKK'dan muaf tutulması gerektiği yönünde görüş bildirmişlerdir. A şirketi yöneticisi "Bu konuda biz sigorta şirketleri olarak KVKK'dan muaf olmak için resmi başvurumuzu Sigorta Bilgi Merkezi aracılığılla yaptık zaten. Sektör olarak; sağlık sigorta şirketleri hastanın sağlığı üzerinden işlem yapan kuruluşlar olduğundan kişilerin sağlık verilerinin kişisel veri kapsamında değerlendirilmemesi gerektiğini düşünüyoruz" sözleri ile açıklamıştır. B şirketi yöneticisi "Toplum olarak genelde hasta olmaya yakın ya da hastalık ortaya yeni çıktığı zamanda sigorta yaptırmaya meyilli olduğumuz için sigorta şirketleri de sigorta yapacağı kişinin sağlık geçmişini bilmek istiyor. Bu düzenleme nedeniyle hastaneler bilgi paylaşmak istemiyor. Bu yasal düzenleme müşterilerin sigorta şirketlerini suiistimal etmesini kolaylaştırıyor." Sözleri ile sigorta şirketlerinin gerekçesini açıklamıştır. Yine D şirketi yöneticisi de "Eksik bilgi kişinin hak etmediği bir güvenceye sahip olmasına ya da hak etmediği tazminatın ödenmesine yol açabilir. Eksik bilgi ile hesaplanan yüksek primler sistemin tıkanmasına, sigortalı kitlesinin daralmasına neden olur" diyerek konunun başka bir boyutuna dikkat çekmiştir.

Sektörün bu kanuna uyum gösterdiği, sigortalı kişiden sigortalılık başlangıcında alınan rıza belgesi ile çözüm sağlanmaya çalışıldığı belirtilmiştir. Ancak özellikle grup poliçelerde her bireyden tek tek imza alınmasının uygulamada çok zor olmasının bir engel teşkil ettiği söylenmiştir. $\mathrm{G}$ şirketi yöneticisinin "Aile adına yapılan poliçede genelde tek bir telefon numarası kaydediliyor. Ailenin tüm üyelerinin sağlık bilgileri paylaşılan tek numara olan bu telefona gidiyor. Aslında 18 yaşın üzerinde olan her birey için ayrı ayrı telefon numarası olmalı ve sadece tek bu kişiye bilgilendirme yapılmalı. Ailenin diğer bireyleri bile bilgilendirmeyi görmemeli" şeklindeki açıklamasında da ifade ettiği üzere aile paketlerinde de aynı sorun yaşanmaktadır.

\section{Tartışma}

Özel sağlık sigortacılığının ülkemizdeki mevcut durumu, sorunları ve geleceği gibi konularda sağlık sigorta ürünü 
satan sigorta şirketlerinin üst düzey yöneticileri ile yapılan çalışmada oldukça değerli bilgiler elde edilmiştir.

Türkiye'de kişilerin satın alma gücüne bakıldığında nüfusun \%10'unun özel sağlık sigortası yaptırma potansiyeline sahip olmasına rağmen bu oran ancak \%2,5-3'lerdedir. Sosyal sağlık sigorta anlayışının hâkim olması, kapsamının geniş olması, kişilerin sigorta bilinçliliğinin düşük olması, kamusal sağlık hizmetlerine duyulan memnuniyet gibi sebepler sigortalı sayısının artması önündeki bariyerler olarak ifade edilmektedir. Ancak başta İstanbul olmak üzere kalabalık nüfusa sahip şehirlerde sağlık hizmetlerine erişimin zorluğu ve zaman alması, gelir durumu yüksek bireylerin daha kaliteli ve konforlu hizmet talebi özel sağlık sigortacılığını artırmaktadır.

Mevcut durum değerlendirildiğinde özel sağlık sigortacılığında en önemli sorunlar olarak; hizmet sunumunda standardı oluşturacak klinik rehberlerin eksikliği, otelcilik hizmetlerinin maliyet artışına neden olması, sigorta şirketleri ile hastaneler arasında yapılan fiyat anlaşmalarının sistemin dengesini bozması, hastanelerin faturalandırma yaparken ödeyici tarafa göre farklı ücretler belirlemesi, arz veya talep taraflı suiistimaller ifade edilmiştir. Mevzuat yönünden fazlaca bir eksiklik hissedilmediği söylenmiş ancak farklı konularda yeni mevzuatların oluşturulmasında sigortacılık sektörünü etkileyecek durumların değerlendirilmesi ve sektörün görüşünün alınması istenmiştir. Yine sigortacılığın, gelecekte yeni ürünler sunabilmesi için -uzun dönemli sigorta gibi- belirlenen hedeflere uygun mevzuat düzenlemesine gerek olduğu ifade edilmiştir. KVKK'nin sektöre ilave bir yük getirdiği, sağlık sigortacılık sektöründe kişilerin sağlık verilerinin kişisel veri kapsamında değerlendirilmemesi gerektiği söylenmiştir.

Hem finansal açıdan sürdürülebilirlik hem de vergi kaybının önlenmesi açısından devletin özel sağlık sigortacılığı desteklemesi gerektiği yönünde fikir birliği olduğu görülmüştür. Ancak devlet teşvikinin yöntemi konusunda farklı görüşler ortaya atılmıştır. Örneğin; özel sağlık sigortası olanlar için SGK prim kesintilerin azaltılabileceği, bireye özgü vergi indirimi sağlanabileceği ya da çalışanlarına özel sağlık sigortası yaptıran kuruluşlara vergi indirimi gibi seçenekler üzerine konuşulmuştur. Devletin BES için yaptığı kampanyaları özel sağlık sigortacılığı için de uygulayabileceği ifade edilmiştir.

Hastanelerin talep ettikleri fark ücretlerinin yüksek olması, sistem kurgulanırken hesaplanandan daha fazla sağlık hizmetinin tüketmesi, SUT fiyatlarında artış olmaması gibi nedenlerin tamamlayıcı sağlık sigortası için tehdit oluşturduğu ve yakın zamanda destekleyici sağlık sigortası ile arasında belirgin bir fark kalmayacağı açıklanmıştır.

Ekonomik durumun yansımasının sigortacılık sektöründe henüz görülmediği fakat önümüzdeki iki yılın zor bir dönem olacağı, sigortalı sayısında ciddi bir düşüş olmasa dahi teminat paketlerinin daralması ve ekonomik ürünler geçiş nedeniyle prim üretiminin azalacağı ifade edilmiştir. Açıklanacak tıbbi enflasyon oranının geçen senelere göre yüksek beklendiği, maliyetlerin artışının kaçınılmaz olduğu ve ister istemez poliçe fiyatlarına da yansıyacağı söylenmiştir.

Görüşme yapılan yöneticilerin bazıları tarafından ülkemizde uzun dönemli sağlık sigortacılığına doğru adım atılması gerektiği ifade edilmişken diğerleri henüz bu ürün için hazır olunmadığı yönünde görüş bildirmiştir. Gelecekte sigortacılık sektöründe dijital uygulamaların yaygınlaşacağı söylenmiştir.

Son olarak; özel sağlık sigortacılığının gelişmesinin devletin sağlık politikaları ile sıkı ilişki içinde olduğuna değinilerek, bu yönde bir düzenleme yapılacak ise sektörün tüm paydaşlarının birlikte çalışması gerekliliği vurgulanmıştır.

\section{Sonuç}

Ülkemizde sosyal sağlık anlayışı hâkimdir ve 5510 Sayılı Kanun'un uygulanmaya başlandığı 2008 yılından 2012 yılına kadar tüm vatandaşlar Genel Sağlık Sigortası kapsamın alınmıştır. Çalışan kişilerin ve işverenlerin gelirleri oranında prim ödediği bu sisteme devlet katkıları da bulunmaktadır. Ancak dünyada olduğu gibi ülkemizde de sağlık hizmetleri için harcamalar her geçen gün artmakta ve finansman için toplanan gelirler ile sağlık harcamaları arasında dengesizlik oluşmaktadır. Tüm ülkelerde yaşanan yaşam süresinin uzaması, teknolojik gelişmeler, hizmet kullanıcıların beklentilerinin artması gibi nedenlere ilaveten ülkemizde sosyal sigorta kapsamının çok geniş olması ve sağlık hizmeti kullanımında görülen artış sağlık finansmanını olumsuz etkilemektedir.

Bununla birlikte bireylerin daha kaliteli ve konforlu sağlık hizmeti talebi, beklemeden muayene ve özel odada tedavi olma gibi istekleri, ülkemizde son yıllarda özel sağlık sigortacılığında gelişim görülmesine yol açmıştır. Ancak gelişmiş ülkeler ile kıyaslandığında ve gelir durumuna göre özel sağlık sigortası yaptırma potansiyeli olan kesim düşünüldüğünde, özel sağlık sigortacılığının sağlık finansmanı içindeki payı hala düşük bir orandır. 
Dünyada sağlık politika yapıcıları ve karar vericilerinin, sağlık finansmanı sorunlarına çözüm arayışlarında harcamaların azaltılması, sağlığın korunması ve geliştirilmesine ağırlık vermekle birlikte finansmanın farklı kaynaklar yoluyla sağlanması ve tüm tarafların maliyetlere

\section{Kaynaklar}

1. WHO. World Health Report 2000. Health Systems: Improving Performance. Geneva: Switzerland; 2000. https://www.who.int/ whr/2000/en/

2. Özer Ö, Yıldııım HH, Yıldırım T. Sağlık Sistemlerinde Finansal Sürdürülebilirlik Kuram ve Uygulama. Ankara: Absam 2015. https:// issuu.com/absamhealth/docs/finansal_surdurulebilirlik

3. Erumut MC. Türkiye için alternatif sağlık finansman önerisi: iki sütunlu sistem. Sosyal Güvence Derg 2014;5:93-122. http://static.dergipark. org.tr/article-download/imported/5000152869/5000138521.pdf?

4. Uğurluoğlu E, Özgen H. Sağlık Hizmetleri Finansmanı ve Hakkaniyet. HacettepeSağlıkidaresiDerg 2008;11:133-59.http://static.dergipark. org.tr/article-download/imported/5000046432/5000043614.pdf?

5. WHO. The World Health Report: Health Systems Financing: The Path To Universal Coverage. Geneva, Switzerland: WHO Press; 2010. https://www.who.int/whr/2010/en/

6. Kılavuz E. Sağlık Harcamalarındaki Artış ve Temel Bakım Hizmetleri. Sosyal Bilimler Enstitüsü Derg 2010;2:173-92. https://arastirmax. com/en/system/files/dergiler/347/makaleler/2/29/arastirmaxsaglik-harcamalarindaki-artis-temel-bakim-hizmetleri.pdf

7. Orhaner E. Türkiye'de Sağlık Hizmetleri Finansmanı ve Genel Sağlık Sigortası. Ticaret ve Turizm Eğitim Fakültesi Derg 2006;1. http:// static.dergipark.org.tr/article-download/725c/9a55/49ec/JA73FF94 CA/5cb720d6839ef_1ce3e371e3c04145deb4aaf11a82327f.pdf?

8. Aytekin S, Aytekin Çiftçi AG. Türkiye'de Sağlık Hizmetleri ve Kamu Sağlık Harcamalarının Finansmanı. Gümüşhane Üniversitesi Sosyal Bilimler ED 2010;2:591-610.

9. Yıldıım HH, Yıldırım T, Erdem R. Sağlık Hizmetleri Finansmanında Kullanıcı Katkıları: Genel Bir Bakış ve Türkiye iç̧in Bir Durum Değerlendirmesi. Amme İdaresi Derg 2011;44:71-98.

10. Yenimahalleli-Yaşar G. Sağlığın Finansmanı ve Türkiye Iç̧in Sağlık Finansman Modeli Önerisi. A. Ü. Sosyal Bilimler Enstitüsü, Doktora Tezi. Danışman: Prof. Dr. Şerife Türcan Özşuca, 2007.

11. İstanbulluoğlu H, Güleç M, Oğur R. Sağlık Hizmetlerinin Finansman Yöntemleri. Dirim Tıp Gazetesi 2010;2:86-99. https://www.dirim. com/Dirim_2010-2_files/Sag\%CC\%86l\%C4\%B1k\%20hizmetleri.pdf

12. Tatar M. Sağlık Hizmetlerinin Finansman Modelleri: Sosyal Sağlık Sigortasının Türkiye'de Gelişimi. Sosyal Güvenlik Derg 2011;1:10333. http://static.dergipark.org.tr/article-download/4494/f715/0ea9/ imp-297504-0.pdf? katkı sağlaması anlayışını destekledikleri görülmektedir. Ülkemizde de alternatif finansman kaynağı olarak özel sağlık sigortacılığının tüm yönleri ile incelenerek, ileri çaIışmalar ile sağlık sistemine etkilerinin değerlendirilmesi gerekmektedir.

13. Özgen H. Sağlık Hizmetleri Finansmanında Cepten Harcama: Nedir? Neden Önemlidir? Hacettepe Sağlık İdaresi Derg 2007;10:201-28. http://static.dergipark.org.tr/article-download/ imported/5000046427/5000043609.pdf?

14. Özsarı SH. Bir Özel Sağlık Sigortacılık Kurumunda Kullanıcıların Özellikleri ve Risk Profilleri. Hacettepe Üniversitesi Sağlık Bilimleri Üniversitesi. Doktora Tezi. Danışman: Prof. Dr. Çağatay Güler 2003.

15. Tunç O, Kıyak M. Private Health Insurance in Europe and Turkey. Journal of Economics, Finance \& Accounting-JEFA 2015;2:3.

16. Preker AS, Scheffler RM, Bassett MC. Private Voluntary Health Insurance in Development. Friend or Foe? The World Bank. Washington, DC; 2007.

17. Arık Özge Avrupa Birliğine Giriş Sürecinde Türkiye'de Özel Sağlık Sigortalarının Durumu ve Avrupa Birliği'ndeki Özel Sağlık Sigortası Uygulamaları Ile Bir Karşılaştırma. Çukurova Üniversitesi Sosyal Bilimler Enstitüsü Iktisat Anabilim Dalı. Yüksek Lisans Tezi. Danışman: Yrd. Doç. Dr. Yelda Tekgül. Adana; 2010.

18. Milli Eğitim Bakanlığı. Pazarlama ve Perakende. Sağlık Sigortası. 2011. http://www.megep.meb.gov.tr/mte_program_modul/ moduller_pdf/Sa\%C4\%9FI\%C4\%B1k\%20Sigortas\%C4\%B1.pdf

19. Alan M. Özel Sağlık Sigortasının Mevcut ve Potansiyel Müşteriler Tarafindan Algılanışı. Doğuş Üniversitesi Sosyal Bilimler Enstitüsü İşletme Anabilim Dalı İşletme Bilim Dalı. Yüksek Lisans Tezi. Danışman: Doç. Dr. Erdoğan Koç. 2009.

20. Özsarı S.H. Genel Sağlık Sigortası ile Özel Sağlık Sigortacılığı Illişkisi. SD Dergisi. 2007;1:142-47. http://www.sdplatform.com/Dergi/9/ Genel-saglik-sigortasi-ozel-saglik-sigortaciligi-iliskisi.aspx

21. Türkiye Sigorta Birliği, İstatistikler. Erişim: https://www.tsb.org.tr/ resmi-istatistikler.aspx?pagelD $=909$

22. OECD. OECD Health Statistics 2019 Definitions, Sources and Methods. Paris. http://www.oecd.org/health/health-data.htm

23. Özsarı SH. Tamamlayıcı Sağlık Sigortası. SD Dergisi. 2018;48:92-3. http://www.sdplatform.com/Dergi/1035/Tamamlayici-SaglikSigortasi-sureci-ve-gelinen-nokta.aspx

24. Türkiye Sigorta Birliği. Sektör Raporu; 2018. https://www.tsb.org.tr/ yayinlar.aspx?pagel $=534$

25. Sigorta Bilgi ve Gözetim Merkezi, İstatistikler. https://www.sbm.org. tr/tr/seyahat-saglik-sigortalari 